\title{
Mobility across the pre-Pyrenean mountain ranges during the Chalcolithic through strontium isotopes in human enamel: La Cueva de los Cristales (Sarsa de Surta, Huesca, Spain)
}

\author{
Vanessa Villalba-Mouco $^{\mathrm{a}, *}$, Manuel Bea ${ }^{\mathrm{a}}$, Lourdes Montes ${ }^{\mathrm{a}}$, Domingo C. Salazar-García ${ }^{\mathrm{b}, \mathrm{c}}$ \\ ${ }^{a}$ Dpt. Sciences of Antiquity-Prehistory, Research Group "Primeros Pobladores y Patrimonio Arqueológico" (PPPA), University Institute of Research into Environmental \\ Sciences (IUCA), University of Zaragoza, C/ Corona de Aragón 42, 50.009 Zaragoza, Spain \\ ${ }^{\mathrm{b}}$ Research Group in Prehistory IT-622-13 (UPV-EHU)/IKERBASQUE, Basque Foundation for Science, Vitoria, Spain \\ ${ }^{\mathrm{c}}$ Department of Geological Sciences, University of Cape Town, Cape Town, South Africa
}

\section{A R T I C L E I N F O}

\section{Keywords:}

Late Neolithic-Chalcolithic

Sepulchral caves

Pre-Pyrenees

Territorial mobility

Bioavailable strontium

\begin{abstract}
A B S T R A C T
There is an increasing abundance in the archaeological record in Iberia for the Late Neolithic and the beginning of the Chalcolithic periods, mostly regarding burials. The higher pre-Pyrenean areas began to be settled more frequently, but the poor weather conditions have led researchers to suggest that human presence mostly took the form of sporadic visits. This argument has provoked substantial controversy given the increase not only in the archaeological artefacts recorded but also in the number of burial sites in less accessible places. To shed more light on the knowledge of these Chalcolithic mountain groups, we have carried out strontium isotope analysis of human enamel of individuals from the funerary cave Cueva de los Cristales (Sarsa de Surta, Huesca, España), located 1,300 $\mathrm{m}$ above sea level (m a.s.l.). Our results point to a pre-Pyrenean origin of the Chalcolithic groups, despite differences found among the individual values, which may be related to different locations in the prePyrenean area. The added value of the study resides in the large amount of data points (up to 40) of bioavailable strontium values which will be useful for future mobility studies performed in the Pyrenean territory.
\end{abstract}

\section{Introduction}

There has been a considerable increase in the funerary archaeological record of the whole Iberian Peninsula relating to the Late Neolithic and the Chalcolithic. This includes sepulchral caves or shelters in those territories where the orography allows (e.g. Utrilla et al., 2015; Fernández-Crespo, 2016; Salazar-García et al., 2016), the construction of megalithic tombs (e.g. Alt et al., 2016; Aranda Jiménez et al., 2018), and even the reuse of dolmens already used as burial sites during Neolithic (Fernández-Eraso and Mujika-Alustiza, 2013). Taken together these findings suggest the possibility of a demographic boost, beyond the ritual changes that could account for the increase in the current visibility of these burial sites. The causes of this demographic increase could lie in migratory movements, a hypothesis that would be supported by the presence of new exogenous objects (Schuhmacher and Banerjee, 2012), or by the intrinsic population increase of the Neolithic groups in the Iberian Peninsula, as the DNA studies may suggest, since no notable changes between Neolithic and Chalcolithic are observed (Szécsényi-Nagy et al., 2017) except for some sporadic contacts with
North African populations that would have had a greater impact in Southern-Middle Iberia (Olalde et al., 2019).

Whatever the reason, both demographic growth as well as trade networks are often linked to an increased mobility among communities as they became increasingly specialized in managing certain types of resources. As a result of this economic stabilization, a homogenous use of these resources occurred, a factor already documented in diet studies based on stable isotope analysis focused on human bone collagen for Late Neolithic and Chalcolithic remains (e.g McClure et al., 2011; Salazar-García, 2011, 2014; García-Borja et al., 2013; Fontanals-Coll et al., 2015; López-Costas et al., 2015; Fernández-Crespo et al., 2017; Waterman et al., 2015; Sarasketa-Gartzia et al., 2018b; Villalba-Mouco et al., 2018a).

During the Chalcolithic, the number of documented archaeological sites increase at the highlands or, at least, there is a higher density of those archaeological remains that allow us to recognise such sites in those areas with the highest altitude in the Iberian Peninsula (Gassiot Balbé et al., 2014). The Pyrenees is a relevant area, with sites dated $\sim 2500$ cal BC (Laborda et al., 2017). These high places with less

\footnotetext{
* Corresponding author.

E-mail address: vvmouco@unizar.es (V. Villalba-Mouco).
} 
favourable climatic conditions seem to suggest a specific use, maybe periodic and recurrent, usually related to livestock management (Montes et al., 2016a; Rojo et al., 2013).

In this context, the concept of territorial mobility is not linked with the term "migration". We consider mobility as the individual or community's spatial distribution throughout their life, not strictly tied to cultural changes, something more related to migratory movements. In connection with molecular techniques applied to human and animal remains, the study of ancient DNA is the essential base to identify large population movements in the past (Haak et al., 2015; Olalde et al., 2018). Otherwise, strontium isotope analysis makes it possible to explain movements at individual or group levels within population groups that may be perfectly homogenous from a genetic point of view (Haak et al., 2008; Knipper et al., 2017).

\subsection{Late Neolithic and Chalcolithic in the Pre-Pyrenees}

The Pre-Pyrenean mountain ranges were occupied throughout Prehistory due to the numerous caves and shelters (Montes and Domingo, 2014), the mixed valley and mountain environment (with a large diversity of natural resources) and milder climatic conditions compared to high mountain areas (González-Sampériz et al., 2017). Human occupation of the Pre-Pyrenees can be documented in every chronology: Middle Palaeolithic (e.g Utrilla et al., 2010; Mora et al., 2008; Domingo and Montes, 2016; Sola et al., 2016), Upper Palaeolithic (e.g. Utrilla and Mazo, 2014; Utrilla and Laborda, 2018; MartínezMoreno et al., 2010), Mesolithic (e.g. Utrilla et al., 2009; Utrilla and Mazo, 2014; Domingo et al., 2018; Berdejo et al., 2018) and Early Neolithic (e.g. Utrilla and Laborda, 2018; Mazzucco et al., 2013; Lancelotti et al., 2014; Rojo et al., 2015).

The number of sites drastically decreased during Middle Neolithic, with human remains documented in just two caves: Cova dels Trocs (Rojo et al., 2013) and Cueva de Chaves (Villalba-Mouco et al., 2018b). In contrast, there are more funerary sites during Late Neolithic and Chalcolithic, both dolmens (e.g. Calvo, 1991a, b) and sepulchral caves (e.g. Lorenzo, 2014) (Fig. 1). Radiocarbon dates for these two types of collective burials seem to overlap in time. The selection of one or other type of place of burial is still unknown, although some studies have tried to analyse this issue from a multi-perspective focus (FernándezCrespo and de-la-Rúa, 2015; Fernández-Crespo and Schulting, 2017).

There is a lack of human settlements during Late Neolithic and Chalcolithic in this territory. All remains obtained from archaeological surveys carried out in the area cannot be ascribed exclusively to the Chalcolithic period. Both flint tools and pottery, most of them without decoration or with cording-like applications, are also documented in other chronological periods (Pérez-Romero et al., 2017), so these isolated findings cannot establish a relative chronology when they appear outside a stratigraphic or chrono-cultural context.

Despite the lack of specific settlements and of a large number of archaeological remains, different fragments of pottery and storage structures in caves have been found, indicating at least, relatively short occupations generally related to herding practises (Baldellou, 1987; Montes and Martínez-Bea, 2006). Some archaeological works have suggested the beginning of these practises in the pre-Pyrenean and the Pyrenean area during the Early Neolithic (e.g Rojo et al., 2014; Clemente Conte et al., 2014). Additionally, new pilot studies are focusing on the direct study of the modern sheep from an isotopic perspective (carbon and oxygen sequential sampling of enamel bioapatite) in order to create a baseline to study the altitudinal mobility of the prehistoric herders (Tornero et al., 2018).

Faunal studies point out the importance of ovicaprine for the human communities that occupied the Pre-Pyrenean region in general and the so-called Tierra Bucho in particular, where the Cueva de los Cristales is located (Montes et al., 2016a, 2016b). Otherwise, other taxa like the domestic pig (Sus domesticus), also present in the territory, could indicate that these human groups should not be restricted to important
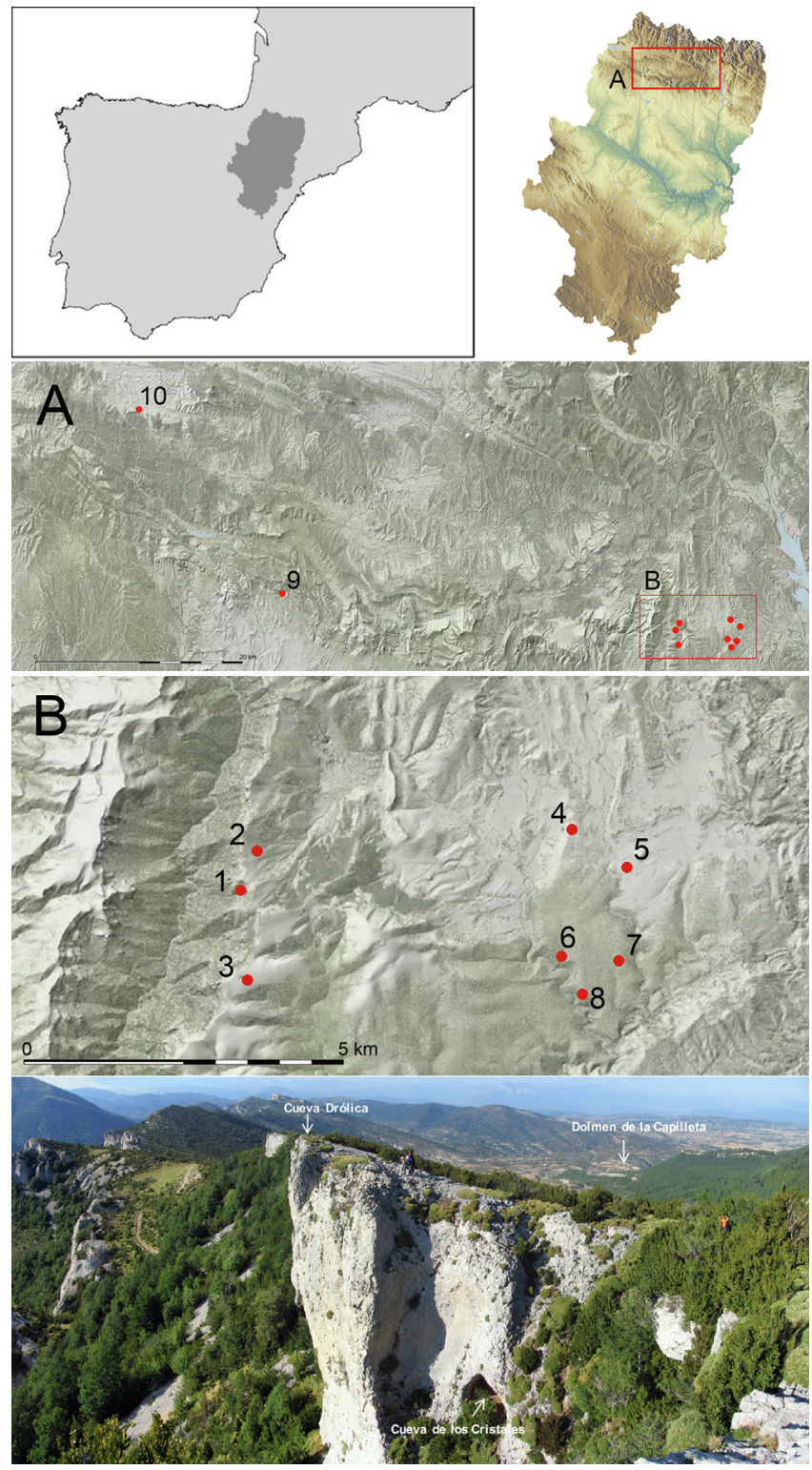

Fig. 1. a) Area of study and its location in the Iberian Peninsula b) Tierra Bucho area where Cueva de los Cristales and 4 other sites cited in the text are located:1. Cueva de los Cristales; 2. Cueva Drólica; 3. Malifeto; 4. Dolmen de la Capilleta; 5. Dolmen Pueyoril; 6. Peña Miel; 7. Dolmen de las Balanzas; 8. Cueva de la Carrasca; 9. San Juan de Loarre; 10. Bailo (not an archaeological site) (above); and Cueva de los Cristales emplacement and its environment (photo R. Domingo) (below).

mobility patterns since this specie is not related to transhumant activities (Montes et al., 2016a, 2016b). Moreover, archaeobotanical studies performed in different Pyrenean and pre-Pyrenean sites suggest more stable stays in the highlands than previously suggested, as the same domestic species have been found in both highland and lowland areas (Antolín et al., 2018).

In the other side of the Pyrenees, also seasonal movements related to transhumance and hunting more than stable stays in the highlands have been proposed since the Early Neolithic (e.g. Geddes, 1983), or even in more distant mountain regions such as Germany (Bentley and Knipper, 2005; Kienlin and Valde-Nowak, 2002-2004), Greece (Chang, 1993) or Eastern Europe (Gerling et al., 2012). The same as in the Southern slope of the Pyrenees, there is a notorious increase in the number of funerary sites, especially regarding megalithic monuments (e.g. Beyneix, 2007). 

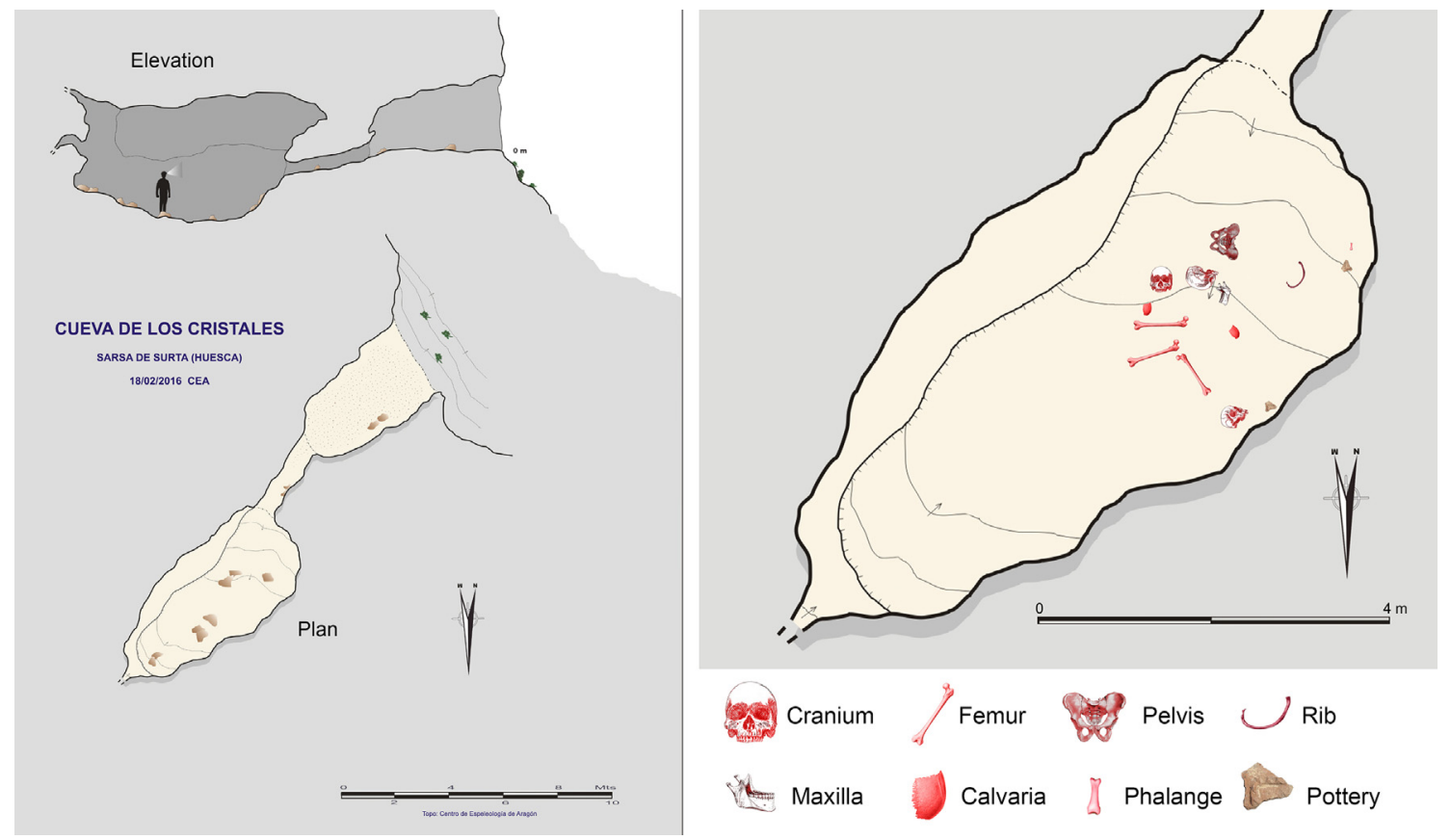

Fig. 2. Topography of the Cueva de los Cristales (left), showing the dispersion of the main archaeological material located inner hall (right) (topography made by Mario Gisbert, Centro de Espelología de Aragón, CEA).

\subsection{Cueva de los Cristales site}

The Cueva de los Cristales site is located at $1,300 \mathrm{~m}$ a.s.l. on the eastern slope of the Isuala river ravine, in today's Aínsa-Sobrarbe municipality (Huesca). The cave (covered with calcite crystals on its walls, 'Cristales' in Spanish) is formed by an entrance-hall and a $7 \mathrm{~m}$ long inner cavity, both of them connected by a narrow corridor (Fig. 1b and 2). The first human remains were recovered in the inner space, and they were apparently deposited on the surface, without any other treatment (Montes and Domingo, 2001-2002). The rest of the skeletal remains were obtained during the archaeological campaign in 2007 (Montes and Martínez-Bea, 2006). All of them appeared commingled and disarticulated, maybe as a result of their simple deposition on the surface of the inner space. This kind of corpse deposition is typical in Chalcolithic collective burials inside caves (e.g. Guixé, 2009; Gimeno, 2009). This chronology was confirmed by the radiocarbon dates of the human bones from the Cueva de los Cristales as well as from other nearby sites (Table 1).

While excavating the Cueva de los Cristales, just a few prehistoric pottery fragments without decoration (assumed to be associated to the burials) together with scarce animal remains (all of them ovicaprine) were collected. Since they have not been directly dated it is not possible to confirm their relationship with the burials, despite the fact that the pottery features can be attributed to the same chronological period.

\subsection{Strontium isotope and the study of territorial mobility}

The mobility studies based on strontium isotope analysis $\left({ }^{87} \mathrm{Sr} /{ }^{86} \mathrm{Sr}\right)$ have proved to be very useful in the archaeological field, not only for faunal (e.g. Britton et al., 2009; Copeland et al., 2016) but also for human remains (e.g. Copeland et al., 2011; Haak et al., 2008). Despite growing interest, ${ }^{87} \mathrm{Sr} /{ }^{86} \mathrm{Sr}$ analysis continues to be underrepresented in the Iberian Peninsula. The majority of such analyses that have been performed have been applied to Chalcolithic and Bronze Age human remains (e.g. Díaz-del-Río et al., 2017; Díaz-Zorita Bonilla et al., 2018; Sarasketa-Gartzia et al., 2018a, 2018b; Villalba-Mouco et al., 2018; Waterman et al., 2014).

Strontium isotope ratio analysis $\left({ }^{87} \mathrm{Sr} /{ }^{86} \mathrm{Sr}\right)$ performed on dental enamel can provide evidence about the use of a territory and human mobility through it on an individual scale (Bentley, 2013). Unlike carbon and nitrogen stable isotopes, ${ }^{87} \mathrm{Sr} /{ }^{86} \mathrm{Sr}$ do not show isotopic fractionation and so the isotopic signature is directly incorporated into human tissues through the water, plants and animals involved in human trophic webs. Among human tissues, dental enamel is the only

Table 1

$2 \sigma$ Calibrated Radiocarbon dates from those sites located in Tierra Bucho area, where Cueva de los Cristales, Cueva Drólica, Dolmen de la Capilleta and Caseta de las Balanzas are located. About Cueva Drólica, only those dates corresponding to the occupation during Chalcolithic. All dates were calibrated with OxCal v4.2.3 and using the IntCal13 calibration curve (Reimer et al., 2013).

\begin{tabular}{|c|c|c|c|c|c|}
\hline Archaeological site & Sample & Lab code & ${ }^{14} \mathrm{C}$ age & Date cal BC $(2 \sigma)$ & Reference \\
\hline Cueva Drólica (ocupation level a) & Charcoal & GrN-30996 & $3790 \pm 60$ & $2457-2038$ & Montes and Martínez-Bea, 2006 \\
\hline Cueva Drólica (ocupation level a) & Charcoal & GrA-25757 & $3830 \pm 45$ & $2460-2146$ & Montes and Martínez-Bea, 2006 \\
\hline Cueva Drólica (ocupation level a) & Charcoal & GrA-33936 & $3975 \pm 35$ & $2579-2349$ & Montes and Martínez-Bea, 2006 \\
\hline Cueva Drólica (ocupation level a) & Charcoal & GrA-33935 & $4000 \pm 35$ & $2619-2462$ & Montes and Martínez-Bea, 2006 \\
\hline Cueva Drólica (ocupation level a) & Charcoal & GrA-38063 & $4105 \pm 30$ & $2864-2506$ & Montes and Martínez-Bea, 2006 \\
\hline Cueva de los Cristales & Human bone & GrN-26967 & $3900 \pm 100$ & $2834-2041$ & Montes et al., 2016b \\
\hline Cueva de los Cristales & Human bone & GrA-38062 & $4121 \pm 30$ & $2867-2581$ & Montes et al., 2016b \\
\hline Cueva de los Cristales & Human bone & GrA-38061 & $4370 \pm 30$ & $3089-2907$ & Montes et al., 2016b \\
\hline Dolmen de la Capilleta & Human bone & GrN-16051 & $4360 \pm 35$ & $3089-2901$ & Calvo, 1991a \\
\hline Dolmen de Caseta de las Balanzas & Human bone & GrN-16052 & $3795 \pm 35$ & $2397-2061$ & Calvo, 1991b \\
\hline
\end{tabular}


one which does not show active remodelling during the individual's life. Enamel mineralization occurs at different times from childhood to early adulthood depending on the dental piece and they trap the strontium isotopic signature at that moment.

Additionally, the ${ }^{87} \mathrm{Sr} /{ }^{86} \mathrm{Sr}$ ratio is directly related to the geology of the area, showing different values according to two main factors, the bedrock age and its amount of ${ }^{87} \mathrm{Rb}$ (Bentley, 2013). ${ }^{87} \mathrm{Sr} /{ }^{86} \mathrm{Sr}$ values associated to geology are fixed in dental enamel during tooth mineralization, reflecting in this way the bioavailable strontium values of the region where the individual lived when and where the enamel mineralization process took place (Bentley, 2006; Ericson, 1985; Price et al., 2002). In this context, the second and third molars (M2 and M3, correspondingly) are usually selected for human mobility studies as they allow a comparison to be made between the ${ }^{87} \mathrm{Sr} /{ }^{86} \mathrm{Sr}$ values recorded during childhood (when mineralization of M2 occurs) and at the beginning of adulthood (mineralization of M3) (Hillson, 1996). Deciduous teeth, whose enamel mineralizes during the period of pregnancy, or teeth whose enamel mineralizes during the potential lactation stage, are ruled out from the analysis since different physiological processes can affect the values of ${ }^{87} \mathrm{Sr} /{ }^{86} \mathrm{Sr}$ (Lugli et al., 2017).

Finally, different environmental conditions, such as the effect of marine aerosols (known as the 'sea spray effect') (Bentley, 2006), as well as the dragging of different geological materials by atmospheric phenomena such as wind, rain or river flows, can alter the expected strontium values for a given geology (Sjögren et al., 2016). These environmental factors could increase or decrease the ${ }^{87} \mathrm{Sr} /{ }^{86} \mathrm{Sr}$ ratio of the surrounding areas depending on the bedrock baseline value. For all these reasons, it is absolutely essential to calculate the specific bioavailable strontium values of a territory by sampling modern plants and snails (Price et al., 2002), and comparing them with human enamel values.

\section{Materials and methods}

\subsection{Human remains from the Cueva de los Cristales}

The total number of human remains recovered from the Cueva de los Cristales was 17 (Alconchel, 2013). Despite their scarcity, the conservation of the remains and the presence of some specific anatomical elements enabled some important anthropological information to be inferred, such as the minimum number of individuals (MNI), the estimation of their biological age, as well as their sex determination (Alconchel, 2013). Based on the skeletal elements and/or specific bone landmarks and taking into account its laterality and age category, the MNI recovered from Cueva de los Cristales was 6. Among them, 2 individuals were ascribed to the age category Infant II (6 to 12 years) with indeterminable sex; 3 adults, two of them masculine and the other of undetermined sex; and one juvenile determined as female (Alconchel, 2013). The methods used in the sexual diagnosis in Alconchel (2013) were based on cranial and mandibular morphology (Brothwell, 1993; Campillo and Subirà, 2004). As neither of the methods used coxal morphology (the anatomical element with highest sexual dimorphism) (e.g. Bruzek, 2002), and the human remains appeared disarticulated and commingled, here we have decided to exclude the published information regarding the sex diagnoses. For the age estimation, Alconchel (2013) used the sinostosis degree of the cranial sutures (Olivier, 1960), dental wear pattern from Brothwell (1993), Perizonius (Campillo and Subirà, 2004: 177) and table of tooth eruption of Schour and Massler (Campillo and Subirà, 2004: 155). No apparent pathology at the macroscopic level was found among the human bones recovered. Most of the dental pieces that appeared isolated are not repeated and cannot be attributed to specific individuals. Among them, only one seems to have been affected by the presence of caries and two of them by enamel hypoplasia. These pathologies are present in fully developed permanent dentition (Alconchel, 2013).

Based on the characteristics of the human remains, finally 5 dental pieces corresponding to 4 different individuals were selected for the strontium isotope analysis (Table 3). All the chosen dental pieces were attached to the mandible or the maxilla, making it possible to rule out the sampling of the same individual twice. In addition, with this sampling strategy more information is obtained about the biological aspects of the individual such as an approximate age estimation with dental eruption patterns (Ubelaker, 1978) and the existence of possible pathologies (Ortner, 2003). When possible, M2 and M3 from the same individual have been selected, with the aim of inferring possible movements at different stages of life: during childhood, when the second molar mineralizes, and at beginning of the adult stage, when the third molar mineralizes (Hillson, 1996) (Table 3). Deciduous teeth and or teeth which potentially mineralize during breastfeeding (incisors and first molars) were ruled out in order to avoid the possible maternal interference on the isotopic values (Lugli et al., 2017). This sampling strategy has already been developed in previous studies of similar chronologies carried out in adjacent territories (Sarasketa-Gartzia et al., 2018a, 2018b).

\subsection{Calculation of the bioavailable ${ }^{87} \mathrm{Sr} /{ }^{86} \mathrm{Sr}$ values of the studied area}

In order to characterize the displacement of different species, we need to know the 'local' strontium isotope baseline. For archaeological studies, we usually use the term 'local' to refer to the area where the individual was recovered. To calculate the isotopic signature of the "local" values, non-mobile biological organisms such as modern plants (Hoppe et al., 1999) and organisms with limited mobility such as snails (Price et al., 2002) have been randomly sampled. Specifically, for this study 5 plants and 5 snails have been sampled in each geological area. We decided to select different geological areas with the same kind of bedrock with the aim of increasing the resolution of our study since the dragging of materials from the Pyrenees (from an older geological age) could have had a greater influence in some of the areas, creating a mosaic of values in the Pre-Pyrenees. In total, we analysed samples from four different geographical areas located along the Pre-Pyrenees (Table 2). The main two areas are the surroundings of the Cueva de los Cristales and Cueva Drólica, whose geological stage of formation would correspond to the lower Paleocene-Eocene (limestones) (called the "Cave area"), and the surroundings of the Dolmens near both caves (Capilleta, Pueyoril and Caseta de las Balanzas), called the "Dolmens area" and corresponding to a geology of the Middle-Upper Eocene (limolites-sandstones) (Fig. 3). At the same time, we included two new geographical areas further away: the surroundings of the town of Arén (the Arén area), whose geology also corresponds to the lower Paleocene-Eocene (clays), and the surroundings of the town of Gabasa (the Gabasa area), whose geology corresponds to an Upper Paleocene-Cretaceous transition zone (sandstones-limestones) (Fig. 3). Previously published bioavailable data from the Pre-pyrenean area have also been added (Villalba-Mouco et al., 2018c).

\subsection{Sample preparation for strontium isotope analysis}

\subsubsection{Dental enamel laboratory procedure}

Sample preparation and analysis were done in dedicated facilities at the Departments of Archaeology (sample preparation) and Geology (analysis) of the University of Cape Town (South Africa). A longitudinal portion of enamel of about $20 \mathrm{mg}$ was taken from each tooth. Each of the fragments was cleaned by abrasion with a Dremel 3500 attached to a diamond head drill bit. For each sample, a different diamond head drill was used, all of them previously washed with ethanol and ultrasonicated in MilliQ water to avoid cross-contamination (Budd et al., 2000). The outer layer was cleaned in order to remove possible remains of the archaeological substrate. The inner part of the enamel was also cleaned to ensure that no dentine remains were present in the analysis. After the mechanical cleaning, the enamel portions were washed with MilliQ water (ultra-distilled and ultra-filtered) and ultrasonicated for 
Table 2

Modern analysed samples, geologic area and ${ }^{87} \mathrm{Sr} /{ }^{86} \mathrm{Sr}$ values for each of them. S-UCT codes with an asterisk were published in Villalba-Mouco et al., 2018c. The geographical location can be consulted in the same publication (Villalba-Mouco et al., 2018c).

\begin{tabular}{|c|c|c|c|c|}
\hline S-UCT (Lab code) & Sample type/Specie & Geological substrate & Area & ${ }^{87} \mathrm{Sr} /{ }^{86} \mathrm{Sr}$ \\
\hline 18297 & Helix sp. & Paleocene-Lower Eocene (limestones) & Cave (Drólica and Cristales) & 0.708023 \\
\hline 18298 & Helix sp. & Paleocene-Lower Eocene (limestones) & Cave (Drólica and Cristales) & 0.708139 \\
\hline 18299 & Helix sp. & Paleocene-Lower Eocene (limestones) & Cave (Drólica and Cristales) & 0.708286 \\
\hline 18300 & Helix sp. & Paleocene-Lower Eocene (limestones) & Cave (Drólica and Cristales) & 0.708155 \\
\hline 18301 & Helix sp. & Paleocene-Lower Eocene (limestones) & Cave (Drólica and Cristales) & 0.707885 \\
\hline 18133 & Herbácea & Paleocene-Lower Eocene (limestones) & Cave (Drólica and Cristales) & 0.708666 \\
\hline 18134 & Buxus sempervirens & Paleocene-Lower Eocene (limestones) & Cave (Drólica and Cristales) & 0.708469 \\
\hline 18135 & Querqus sp. & Paleocene-Lower Eocene (limestones) & Cave (Drólica and Cristales) & 0.709424 \\
\hline 18136 & Buxus sempervirens & Paleocene-Lower Eocene (limestones) & Cave (Drólica and Cristales) & 0.708240 \\
\hline 18137 & Abies sp. & Paleocene-Lower Eocene (limestones) & Cave (Drólica and Cristales) & 0.708465 \\
\hline 18302 & Helix sp. & Middle-Upper Eocene (limolites-sandstones) & Dolmen & 0.707875 \\
\hline 18303 & Helix sp. & Middle-Upper Eocene (limolites-sandstones) & Dolmen & 0.707932 \\
\hline 18304 & Helix sp. & Middle-Upper Eocene (limolites-sandstones) & Dolmen & 0.707869 \\
\hline 18305 & Helix sp. & Middle-Upper Eocene (limolites-sandstones) & Dolmen & 0.707891 \\
\hline 18306 & Helix sp. & Middle-Upper Eocene (limolites-sandstones) & Dolmen & 0.707870 \\
\hline 18138 & Buxus sempervirens & Middle-Upper Eocene (limolites-sandstones) & Dolmen & 0.708024 \\
\hline 18139 & Pinus sp. & Middle-Upper Eocene (limolites-sandstones) & Dolmen & 0.708095 \\
\hline 18,140 & Juniperus sp. & Middle-Upper Eocene (limolites-sandstones) & Dolmen & 0.708018 \\
\hline 18,141 & Herbaceous & Middle-Upper Eocene (limolites-sandstones) & Dolmen & 0.708110 \\
\hline 18,142 & Querqus sp. & Middle-Upper Eocene (limolites-sandstones) & Dolmen & 0.707920 \\
\hline 18,312 & Helix sp. & Paleocene-Lower Eocene (clays) & Arén & 0.708230 \\
\hline 18,313 & Helix sp. & Paleocene-Lower Eocene (clays) & Arén & 0.708165 \\
\hline 18,314 & Helix sp. & Paleocene-Lower Eocene (clays) & Arén & 0.708392 \\
\hline 18,315 & Helix sp. & Paleocene-Lower Eocene (clays) & Arén & 0.708219 \\
\hline 18,316 & Helix sp. & Paleocene-Lower Eocene (clays) & Arén & 0.708220 \\
\hline 18,148 & Querqus sp. & Paleocene-Lower Eocene (clays) & Arén & 0.709052 \\
\hline 18,149 & Buxus sempervirens & Paleocene-Lower Eocene (clays) & Arén & 0.708426 \\
\hline 18,150 & Querqus sp. & Paleocene-Lower Eocene (clays) & Arén & 0.708233 \\
\hline 18151 & Buxus sempervirens & Paleocene-Lower Eocene (clays) & Arén & 0.708246 \\
\hline 18152 & Herbaceous & Paleocene-Lower Eocene (clays) & Arén & 0.709410 \\
\hline 18287 & Helix sp. & Paleocene- Upper Cretaceous (sandstones-limestones) & Gabasa & 0.708476 \\
\hline 18,288 & Helix sp. & Paleocene- Upper Cretaceous (sandstones-limestones) & Gabasa & 0.708513 \\
\hline 18,289 & Helix sp. & Paleocene- Upper Cretaceous (sandstones-limestones) & Gabasa & 0.708375 \\
\hline 18,290 & Helix sp. & Paleocene- Upper Cretaceous (sandstones-limestones) & Gabasa & 0.708530 \\
\hline 18,291 & Helix sp. & Paleocene- Upper Cretaceous (sandstones-limestones) & Gabasa & 0.708555 \\
\hline 18,123 & Querqus sp. & Paleocene- Upper Cretaceous (sandstones-limestones) & Gabasa & 0.709246 \\
\hline 18,124 & Buxus sempervirens & Paleocene- Upper Cretaceous (sandstones-limestones) & Gabasa & 0.709184 \\
\hline 18,125 & Juniperus sp. & Paleocene- Upper Cretaceous (sandstones-limestones) & Gabasa & 0.708657 \\
\hline 18126 & Rosmarinus officinalis & Paleocene- Upper Cretaceous (sandstones-limestones) & Gabasa & 0.708582 \\
\hline 18127 & Herbaceous & Paleocene- Upper Cretaceous (sandstones-limestones) & Gabasa & 0.708751 \\
\hline $18277^{*}$ & Helix sp. & Cretaceous-Miocene (limestones-conglomerates) & Loarre & 0.708943 \\
\hline $18278^{*}$ & Helix sp. & Cretaceous-Miocene (limestones-conglomerates) & Loarre & 0.708275 \\
\hline $18279 *$ & Helix sp. & Cretaceous-Miocene (limestones-conglomerates) & Loarre & 0.708729 \\
\hline $18280^{*}$ & Helix sp. & Cretaceous-Miocene (limestones-conglomerates) & Loarre & 0.708266 \\
\hline 18281* & Helix sp. & Cretaceous-Miocene (limestones-conglomerates) & Loarre & 0.708243 \\
\hline $18113^{*}$ & Herbaceous & Cretaceous-Miocene (limestones-conglomerates) & Loarre & 0.709984 \\
\hline $1811^{*}$ & Buxus sempervirens & Cretaceous-Miocene (limestones-conglomerates) & Loarre & 0.708322 \\
\hline $18115^{*}$ & Querqus ilex & Cretaceous-Miocene (limestones-conglomerates) & Loarre & 0.708915 \\
\hline $18116^{*}$ & Juniperus sp. & Cretaceous-Miocene (limestones-conglomerates) & Loarre & 0.708291 \\
\hline $18117^{*}$ & Rubus ulmifolius & Cretaceous-Miocene (limestones-conglomerates) & Loarre & 0.708378 \\
\hline 18419* & Oryctolagus sp. (archaeological tooth) & Cretaceous-Miocene (limestones-conglomerates) & Loarre & 0.708490 \\
\hline $18420^{*}$ & Oryctolagus sp. (archaeological tooth) & Cretaceous-Miocene (limestones-conglomerates) & Loarre & 0.709047 \\
\hline $18423^{*}$ & Oryctolagus sp. (archaeological tooth) & Cretaceous-Miocene (limestones-conglomerates) & Loarre & 0.708710 \\
\hline $18421^{*}$ & Bufo sp. (archaeological tooth) & Cretaceous-Miocene (limestones-conglomerates) & Loarre & 0.708885 \\
\hline $18422^{*}$ & Talpa sp. (archaeological tooth) & Cretaceous-Miocene (limestones-conglomerates) & Loarre & 0.708506 \\
\hline $18307^{*}$ & Helix sp. & Oligocene (conglomerates-marls) & Bailo & 0.707986 \\
\hline 18308* & Helix sp. & Oligocene (conglomerates-marls) & Bailo & 0.708031 \\
\hline $18309^{*}$ & Helix sp. & Oligocene (conglomerates-marls) & Bailo & 0.708096 \\
\hline $18310^{*}$ & Helix sp. & Oligocene (conglomerates-marls) & Bailo & 0.708004 \\
\hline $18311^{*}$ & Helix sp. & Oligocene (conglomerates-marls) & Bailo & 0.708189 \\
\hline $18143^{*}$ & Herbaceous & Oligocene (conglomerates-marls) & Bailo & 0.708306 \\
\hline $18144^{*}$ & Pistacia lentiscus & Oligocene (conglomerates-marls) & Bailo & 0.708249 \\
\hline $18145^{*}$ & Pinus sp. & Oligocene (conglomerates-marls) & Bailo & 0.708283 \\
\hline $18146^{*}$ & Juniperus sp. & Oligocene (conglomerates-marls) & Bailo & 0.708270 \\
\hline $18147^{*}$ & Buxus sempervirens & Oligocene (conglomerates-marls) & Bailo & 0.708060 \\
\hline
\end{tabular}

$20 \mathrm{~min}$. The cleaned enamel pieces were digested in $2 \mathrm{ml}$ of $65 \%$ bidistilled $\mathrm{HNO}_{3}$ in a closed Teflon beaker placed on a hotplate at $140{ }^{\circ} \mathrm{C}$ for an hour. After digestion, the enamel samples were then dried and redissolved in $1.5 \mathrm{ml}$ of $2 \mathrm{M}$ bidistilled $\mathrm{HNO}_{3}$. These redissolved samples were centrifuged at $4000 \mathrm{rpm}$ for $20 \mathrm{~min}$, and the resulting supernatant was collected for strontium separation chemistry. In this step, a separate fraction was used to determine the concentration of Sr by using a regression equation obtained from the SRM987 standard and its ${ }^{88} \mathrm{Sr}(\mathrm{V})$ intensity signal emitted at different concentrations. The rest of the volume was used to carry out the chemical separation of strontium with $200 \mu \mathrm{l}$ of Eichrom Sr.Spec resin loaded in $2 \mathrm{ml}$ Bio-Spin Disposable Chromatography Bio-Rad Columns following the method of Pin et al. 


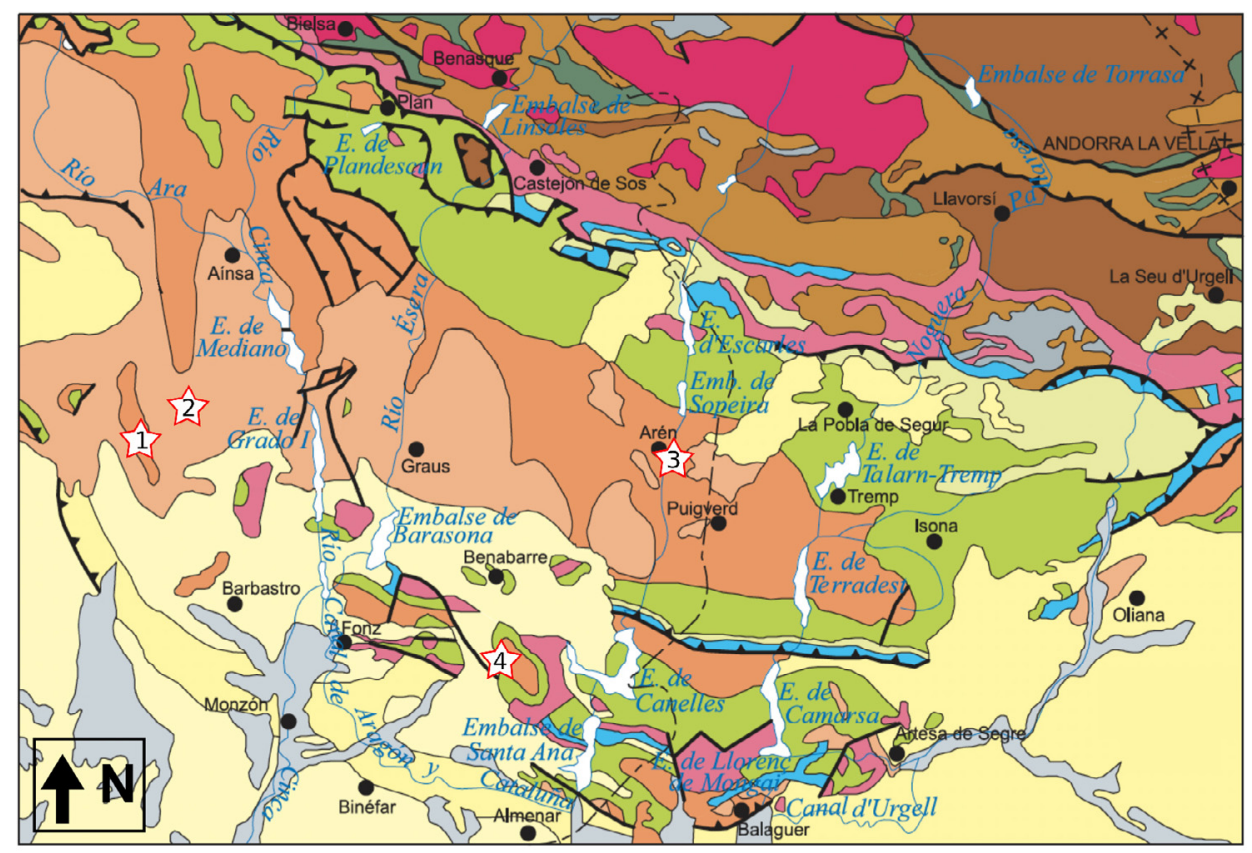

Escale 1:1.000.000

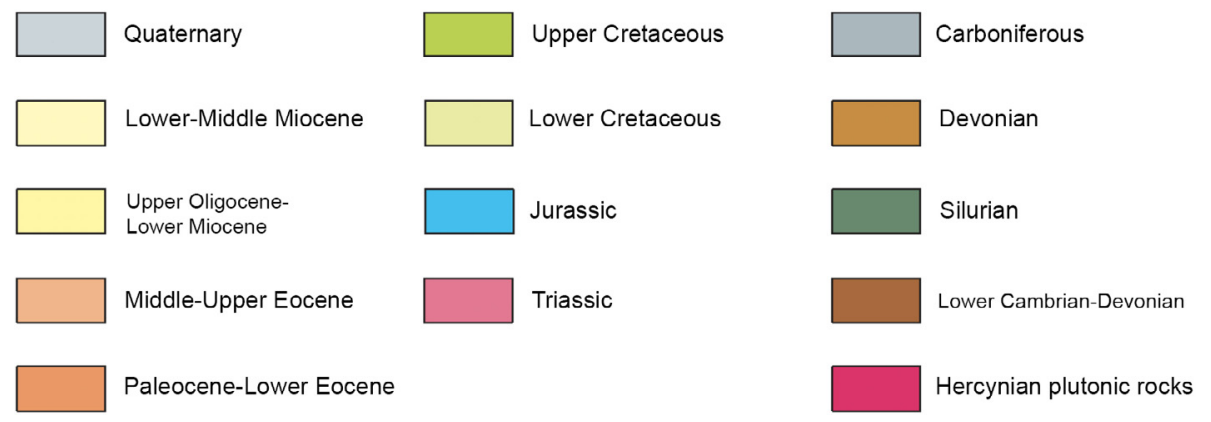

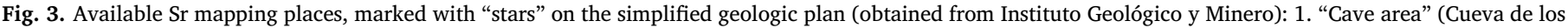
Cristales and Cueva Drólica); 2. "Dolmen area": Dolmen de la Capilleta, Casa de las Balanzas and Pueyoril; 3. Arén surroundings; 4. Gabasa surroundings.

(1994). The separated strontium fraction for each sample was dried, dissolved in $2 \mathrm{ml}$ of $0.2 \%$ distilled $\mathrm{HNO} 3$ and diluted to $200 \mathrm{ppb} \mathrm{Sr}$ concentrations for isotope analysis. ${ }^{87} \mathrm{Sr} /{ }^{86} \mathrm{Sr}$ ratios were measured using a NuPlasma HR multicollector inductively-coupled-plasma mass spectrometer (MC-ICP-MS). Sample analyses were referenced to bracketing analyses of SRM987, using a ${ }^{87} \mathrm{Sr} /{ }^{86} \mathrm{Sr}$ reference value of 0.710255 from the NIST (National Institute of Standards and Technology). The isobaric interference signal caused by rubidium was also corrected by measuring ${ }^{85} \mathrm{Rb}$ and the natural ${ }^{85} \mathrm{Rb} /{ }^{87} \mathrm{Rb}$ ratio. Instrumental mass fractionation was corrected using the measured ${ }^{86} \mathrm{Sr} /{ }^{88} \mathrm{Sr}$ ratio and the exponential law, and a true ${ }^{86} \mathrm{Sr} /{ }^{88} \mathrm{Sr}$ value of 0.1194 .

As controls of the process, the processed standards were measured at the same time as the samples in this study $\left({ }^{87} \mathrm{Sr} /{ }^{86} \mathrm{Sr}=0.708936 ; 2\right.$ sigma $0.000041 ; n=33$ ) and the values were found to be consistent with the data that had been produced so far in the laboratory $\left({ }^{87} \mathrm{Sr} /{ }^{86} \mathrm{Sr}\right.$; $0.708915 ; 2$ sigma 0.000047; $\mathrm{n}=125$ ). Additionally, one blank per batch was added throughout the process to rule out cross-contamination at any point (Table 3, Fig. 4b).

\subsubsection{Modern samples laboratory procedure}

The bioavailable ${ }^{87} \mathrm{Sr} /{ }^{86} \mathrm{Sr}$ range values from the two different geological areas were calculated with plants and snails following the indications of Bentley et al. (2004) and Price et al. (2001). In the case of snail shells, strontium extraction and purification steps were the same as described above. For plants, the previous calcination of the green parts and the digestion of the ashes was necessary, which in this case was carried out by $48 \% \mathrm{HF}$ and $65 \%$ double-distilled $\mathrm{HNO}_{3}$ in 4: 1 proportions respectively, such as described in Copeland et al. (2016). In the case of the current samples, the Sr concentrations were not measured in modern samples since it is assumed that they would not be affected by the possible $\mathrm{Sr}$ diagenetic incorporation (Table 2, Fig. 4a).

\section{Results}

\section{1. ${ }^{87} \mathrm{Sr} /{ }^{86} \mathrm{Sr}$ bioavailable values in modern samples}

The bioavailable ${ }^{87} \mathrm{Sr} /{ }^{86} \mathrm{Sr}$ values calculated with plants and snails from the different sampled study areas are presented in Table 2 and Fig. 4a. Firstly, we applied the Mann-Whitney statistical test to ascertain whether the two different geographical but not geological areas located in the pre-Pyrenees "Cave area" and "Arén area" can be considered isotopically identical in which case the values could be grouped together. The result of this test indicates that there are no significant differences between these two zones $(p=0.734)$, so we grouped the bioavailable $\mathrm{Sr}$ values from both areas in order to gain higher statistical resolution when determining the origin of the individuals. The rest of the sampling areas were kept separate as they belong to different geologies. It is of interest to point out that most of the outliers (4/5) (Fig. 4a) are represented by tree or shrub species, whose roots cling more deeply to the substratum, while none are represented by snails. 
Table 3

${ }^{87} \mathrm{Sr} /{ }^{86} \mathrm{Sr}$ values and $\mathrm{Sr}$ concentration for each dental human enamel sample with its corresponding archaeological ID and laboratory code.

\begin{tabular}{|c|c|c|c|c|c|}
\hline S-UCT (Lab code) & Archaeological ID & Individual age & Sampled tooth & ${ }^{87} \mathrm{Sr} /{ }^{86} \mathrm{Sr}$ & Concentration $\mathrm{Sr}(\mathrm{ppm})$ \\
\hline 18414 & 0739.sup.1P & Subadult & M2 & 0.708502 & 246.4 \\
\hline 18415 & 0739.sup.26 & Adult & M2 & 0.707972 & 191.5 \\
\hline 18416 & 0739.sup.20 & Adult & M2 & 0.708016 & 146.4 \\
\hline 18417 & 0739.sup. 20 & Adult & M3 & 0.708424 & 87.06 \\
\hline 18418 & 0123.sup.9 & Adult & M2 & 0.708200 & 113.0 \\
\hline
\end{tabular}

Another possible explanation for the variability of Sr values in plants and not in snails can be the averaging effect which creates lower ranges of variability in the upper levels of the food chain (Burton et al., 1999).

Finally, the range of ${ }^{87} \mathrm{Sr} /{ }^{86} \mathrm{Sr}$ values for the Lower PaleoceneEocene (Caves and Arén area) is 0.707885-0.709424, for the Dolmens area (Middle-Upper Eocene) 0.707869-0.708110, and for Gabasa (Upper Paleocene-Cretaceous) 0.708375-0.709246. The range of published ${ }^{87} \mathrm{Sr} /{ }^{86} \mathrm{Sr}$ values for Loarre (Cretaceous-Miocene) is 0.708243-0.709984, and for Bailo (Upper Oligocene-Lower Miocene) 0.707986-0.708306, both areas also located in the Pre-Pyrenees whose values have been incorporated in this current study (Villalba-Mouco et al., 2018c).

\section{2. ${ }^{87} \mathrm{Sr} /{ }^{86} \mathrm{Sr}$ values in archaeological samples}

We have performed the analysis of Sr isotopes in five teeth of four Chalcolithic individuals recovered from the Cueva de los Cristales. The ${ }^{87} \mathrm{Sr} /{ }^{86} \mathrm{Sr}$ ratio and $\mathrm{Sr}$ concentrations in parts per million (ppm) of human enamel samples are shown in Table 3 . The ${ }^{87} \mathrm{Sr} /{ }^{86} \mathrm{Sr}$ data for human dental enamel are portrayed in Fig. 4b. All the individuals show dental enamel ${ }^{87} \mathrm{Sr} /{ }^{86} \mathrm{Sr}$ values compatible with the bioavailable ${ }^{87} \mathrm{Sr} /{ }^{86} \mathrm{Sr}$ values from different areas of the Pre-Pyrenees (Fig. 4a). If we focus on the closest areas, the human ${ }^{87} \mathrm{Sr} /{ }^{86} \mathrm{Sr}$ values are included within the range of the Cueva de los Cristales (Cave area, as well as all areas whose geological substrate is Paleocene). Two of them, i.e. $50 \%$ of the sample (0739.sup.26 and M2 value of 0739.sup.20) would also be included in the range of the Dolmens area (Eocene geological substrate), which is at the same time included within the values of the Cave area, but always showing lower ${ }^{87} \mathrm{Sr} /{ }^{86} \mathrm{Sr}$ values (Fig. 4b). Individual 0739.sup. 20 is the only one that shows ${ }^{87} \mathrm{Sr} /{ }^{86} \mathrm{Sr}$ values on different dental pieces (M2 and M3) with lower ${ }^{87} \mathrm{Sr} /{ }^{86} \mathrm{Sr}$ values in its M2 (common to the lower bioavailable values of the Paleocene and all the Eocene values) and higher Sr values in its M3 (Fig. 4b, Table 3).

\section{Discussion}

In order to carry out a study of territorial mobility through strontium isotopic analysis of the individuals from the Cueva de los Cristales, we have performed an intense mapping strategy of the bioavailable strontium values in the Pre-Pyrenees (Figs. 3 and 4). Moreover, we have also compiled those already published from nearby geographical areas (Villalba-Mouco et al., 2018c). The first observation that we extract from the data is that there is a large overlap between the values of the different areas, something that would be related to their chronology, since most are attributed to various geological stages between the $\mathrm{Pa}$ leocene and the Eocene. Nevertheless, with the exception of geographical areas where two geological substrates are in contact (contact areas) as in the San Juan Cave (Loarre) (Villalba-Mouco et al., 2018; Pastor and Vicente, 2009), we can observe that there is a correlation between higher ${ }^{87} \mathrm{Sr} /{ }^{86} \mathrm{Sr}$ values in the Pre-Pyrenees areas with older geological substrates, usually located in the most elevated areas. Thanks to this correlation we see, for example, in the "Cave Area" region (ca. 1,300 $\mathrm{m}$ a.s.l.) higher values than in the "Dolmens area" (ca. $800 \mathrm{~m}$ a.s.l.), although their lower values overlap with the latter (Fig. 4a, Table 3).

This large overlap limits the interpretation of the results and makes it very difficult to identify a specific origin of the individuals. The fact that many areas have statistically similar ${ }^{87} \mathrm{Sr} /{ }^{86} \mathrm{Sr}$ values across the Pre-pyrenees means that the number of 'non local' individuals can be underestimated. Therefore, our bioavailable $\mathrm{Sr}$ values calculated for the
A

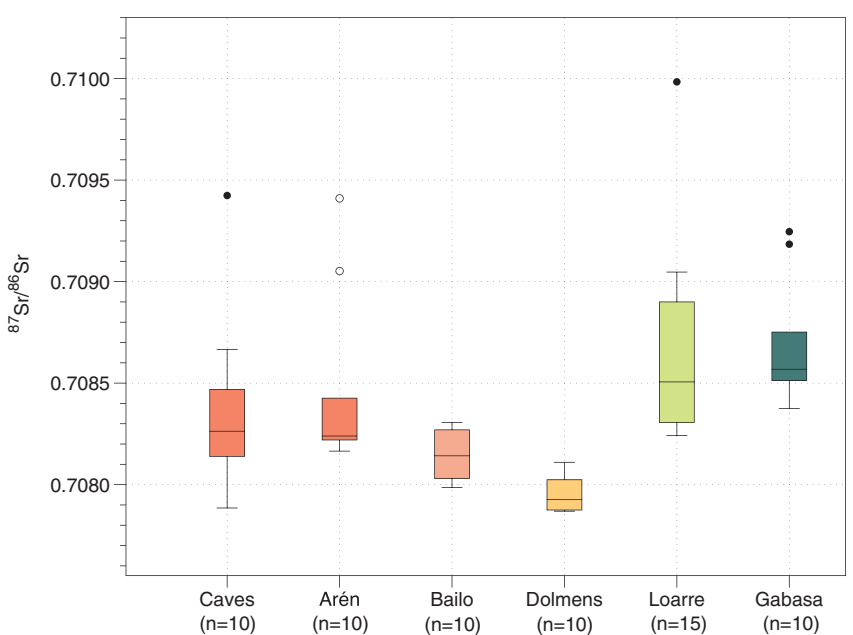

B

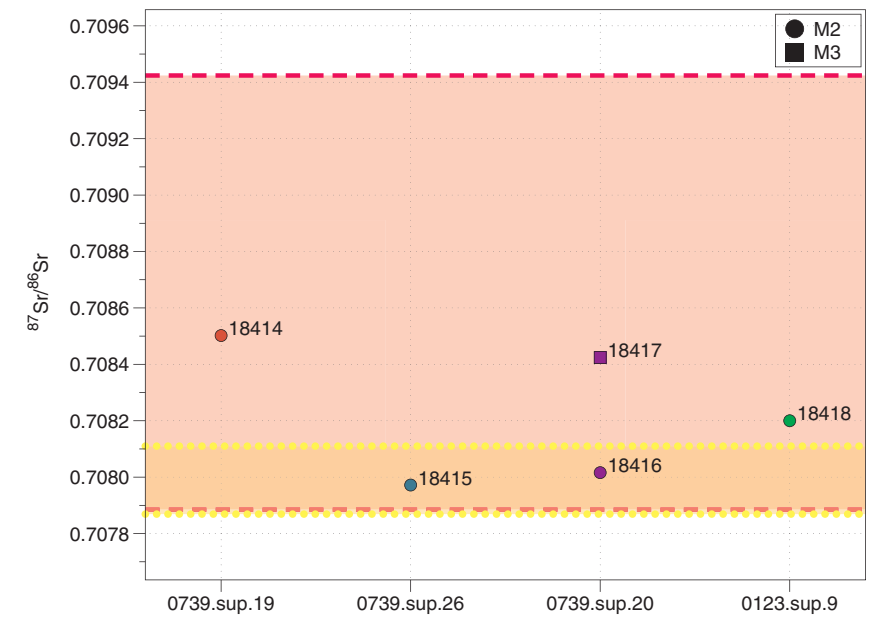

Fig. 4. a). Bioavailable values calculated from current plants and snails. "Cuevas" and "Arén": Lower Paleocene-Eocene; "Bailo": Upper Oligocene-Lower Miocene; "Dólmenes": Middle-Upper Eocene; "Loarre": Cretaceous-Miocene; "Gabasa": Paleocene-Upper Cretaceous. The values from Cueva de San Juan de Loarre also include micro-vertebrate enamel and are published, together with those from Bailo, in Villalba-Mouco et al., 2018c. b). Sr values in human enamel projected on the bioavailable Sr range values from the two main studied areas (Lower Paleocene-Eocene: "Cave area", pink colour delimited by two discontinuous lines; Middle-Upper Miocene: "Dolmen area" zone, orange colour framed by yellow dots). Circles correspond to Sr values measured on M2 and squares on M3. Each colour represents one individual. 
pre-Pyrenees fall in the same range of the published ones for some areas of the French Pyrenees, the Massif Central and other mountainous areas in France (Willmes et al., 2018). Based on the number of common areas with similar ${ }^{87} \mathrm{Sr} /{ }^{86} \mathrm{Sr}$ bioavailable values, we have considered the most proximal bioavailable matching values as indicating the most plausible origin of the individuals. For this reason, most of our discussion is focused on the two closest areas, the Cave area and the Dolmen area.

The individuals of the Cueva de los Cristales show values commonly found in the closest areas ("Dolmens and Cave area") but some of them show values exclusive to the closest higher areas ("Cave area"). This data could suggest the existence of communities that would have inhabited the higher areas permanently or semi-permanently, or at least they would have taken advantage of resources from these areas. These values compatible with the closest high regions of the Pre-Pyrenees are also present in the M2, which means that the individuals could have inhabited this area since their childhood, although we cannot determine the possible movements of the individual from childhood to the age of death since we do not have the M3s of three out of the four humans analysed. Additionally, there are two individuals whose ${ }^{87} \mathrm{Sr} /{ }^{86} \mathrm{Sr}$ could be attributed to both areas (Caves and Dolmens): individual 0739.sup.26 (measurement made in the M2, S-UCT 18415) and individual 0739.sup.20 (measurement made in the M2, S-UCT 18416). In the case of the latter, we also have the values of the third molar (M3, S-UCT 18417), which overlap exclusively with the "Cave area". This change in the ${ }^{87} \mathrm{Sr} /{ }^{86} \mathrm{Sr}$ values of its enamel could indicate a movement from the lowest areas of Tierra Bucho (in our case the Dolmens area, ca. $870 \mathrm{~m}$ a.s.1.) to the highest mountain area where the Cueva de los Cristales is located (1,320 m a.s.l.) during the late childhood (Figs. 1 and 2). The mortality profile of Cueva de los Cristales shows that two out of six individuals were subadults but none of them younger than 6-12 years (Infant II) (Alconchel, 2013). Both results together could suggest a movement of the individuals only when they were able to do it by themselves, from an advanced childhood and onwards, as it could reflect our last example.

The Cueva Drólica (ca. $1200 \mathrm{~m}$ a.l.s.) is located around $300 \mathrm{~m}$ from the Cueva de los Cristales (Fig. 1b). Unlike the Cueva de los Cristales whose function is exclusively funerary, the Cueva Drólica reveals a dwelling phase that is contemporary with the funerary use of the Cueva de los Cristales (Table 1). A large bell beaker vessel was recovered from this archaeological phase whose dimensions point to its use as a storage beaker. Some human remains have also appeared in the Cueva Drólica but so far they all date from a more advanced chronology (Montes and Martínez-Bea, 2006). In contrast, only a few fragments of undecorated pottery have been found in the Cueva de los Cristales (Montes and Martínez-Bea, 2006).

The fact of finding a cave with occupation levels, and not exclusively funerary, would support the hypothesis of the existence of more or less long stays in the higher areas of the Pre-pyrenean ranges. Although the occupations might not have been permanent, the fact that the enamels show the ${ }^{87} \mathrm{Sr} /{ }^{86} \mathrm{Sr}$ signature of this area and none other more characteristic of the lower areas of the Pre-Pyrenees might indicate that the connection with the higher zones would be frequent. However, none of the analyzed individuals show ${ }^{87} \mathrm{Sr} /{ }^{86} \mathrm{Sr}$ values that exceed the calculated bioavailable ${ }^{87} \mathrm{Sr} /{ }^{86} \mathrm{Sr}$ values in the pre-Pyrenean ranges. This leads us to discard the certainty of a long-term settlement in the highest areas of the Pyrenees (exceeding 1,500 $\mathrm{m}$ a.s.1.), which are generally dominated by the presence of older geological substrates and, therefore, with potentially higher Sr values (Bentley, 2006) (Fig. 3). The territory located to the north of the Cueva de los Cristales would be an exception as the Paleocene geological substrates reach up to app. $1800 \mathrm{~m}$ a.s.l. here (e.g. Valle de Broto). In this scenario, we cannot rule out that individuals could have spent their childhood or early adulthood in this highland area.

As discussed above, several areas of the Pre-Pyrenees share common values of ${ }^{87} \mathrm{Sr} /{ }^{86} \mathrm{Sr}$ which makes it difficult to rule out a different origin of individuals. Therefore, it is always necessary to complement isotopic studies with the available archaeological data. Based on the archaeological data provided by archaeological sites from this studied area, the presence of annual movements to high altitudes, for the exploitation of pastures of the nearby mountain passes (Asba, Sevil) has been proposed, corresponding to the so-called "Dolmens area" (Montes et al., 2016a, 2016b). At the same time, the same authors proposed that there were some groups that could have stayed in the Cueva Drólica (Cave area) for longer periods, probably related to altitudinal transhumance or transterminance (Montes et al., 2016a, 2016b). In order to study this hypothesis into detail, it would be necessary to perform sequential isotopic analysis (e.g strontium, oxygen and/or carbon) in domestic ovicapride bioapatite enamel. This methodology provides the resolution to detect short-term movements (e.g Tornero et al., 2018; Balasse et al., 2017). Contrary, Sr analysis in bulk human enamel only reflect the mobility of the individuals in two specific time windows, early childhood and late adolescence. Nevertheless, human Sr values have been used in other studies to approach this question indirectly, suggesting a higher range of $\mathrm{Sr}$ values among individuals in semi-mobile herder societies and a narrower range in sedentary farmers from France (Goude et al., 2012). According with that, the presence of different values of $\mathrm{Sr}$ in human enamel from Cueva de los Cristales, as well as intermediate values between both areas, could support the hypothesis suggested by the archaeological record in this territory (Montes et al., 2016a, 2016b).

In future studies it would be interesting to compare the data of individuals from the nearby dolmens of Capilleta, Caseta de las Balanzas and Pueyoril to see if compatible isotopic values may be found in both areas.

\section{Conclusions}

A study of the bioavailable values of strontium has been carried out along the Pre-Pyrenees together with a dental enamel strontium analysis from human remains recovered from the Cueva de los Cristales. We have confirmed that the mountain areas of the pre-Pyrenees all show similar values. Therefore, the area of origin of the individuals could not be defined with a high degree of accuracy. Even so, two of the individuals show low values that could correspond to more recent geologic areas, such as those near the Ebro basin, where quaternary deposits are predominant, or the lowest areas of the pre-Pyrenees, with a Eocene deposit predominance, showing lower values and conforming a less abrupt relief than the pre-Pyrenees mountain ranges.

Our results suggest that during Chalcolithic there were human communities occupying these two landscape types, since strontium values exclusive to a high mountain area are documented at the same time as those characteristics of lower altitude areas of the pre-Pyrenees, despite the fact that movements between both areas would have taken place during different life stages. None of the studied individuals show out of range values for Paleocene deposits. This rules out permanent settling in the highest areas of the Pyrenees, where older geological substrates appear with potentially higher strontium values.

\section{CRediT authorship contribution statement}

Vanessa Villalba-Mouco: Conceptualization, Data curation, Visualization, Formal analysis, Writing. Manuel Bea: Conceptualization, Visualization, Writing. Lourdes Montes: Funding acquisition, Resources. Domingo C. Salazar-García: Funding acquisition, Supervision.

\section{Declaration of Competing Interest}

The authors declare that they have no known competing financial interests or personal relationships that could have appeared to influence the work reported in this paper. 


\section{Acknowledgements}

We are grateful to Izaskun Sarasketa and Fayrooza Ragoot for their help and assistance during Laboratory works; Rafael Laborda and Mario Gisbert for their help in relocating the cave, collecting the samples for measuring the Sr available in the "Cave area" and for the topographic model of the Cueva de los Cristales site. We are also grateful to Pilar Mouco for her helping-hand during Sr sample collecting in the "Dolmen area", to Jesús Laborda for collecting samples in the "Arén and Gabasa areas"; and also to Rafael Domingo for providing the pictures.

This paper is part of the PhD by V. V-M., funded by a pre-doctoral grant from the Government of Aragón and European Social Fund (BOA20150701025), after having stayed as a pre-Doctoral researcher at the University of Cape Town thanks to an Ibercaja-CAI grant (2016), supervised by D. C. S.G.

V. V-M., M.B. and L.M. are members of the Research Group H-14: PPVE and Project (Gaps and Sites: Vacíos y ocupaciones en la Prehistoria de la Cuenca del Ebro) (ref.: HAR2017-85023-P).

We are also grateful to Julian Chancellor and Megan Michel for the English revision of the text.

\section{References}

Alconchel, L., 2013. Paleoantropología del alto Vero en el Calcolítico: las cuevas Drólica y de los Cristales y el dolmen de la Caseta de las Balanzas. Bolskan 24, 27-38.

Alt, K.W., Zesch, S., Garrido-Pena, R., Knipper, C., Szécsényi-Nagy, A., Roth, C., TejedorRodríguez, C., Held, P., García-Martínez-de-Lagrán, I., Navitainuck, D., Arcusa, H., Rojo-Guerra, M.A., 2016. A Community in Life and Death: The Late Neolithic Megalithic Tomb at Alto de Reinoso (Burgos, Spain). PLOS ONE, 11 (1), e0146176.

Antolín, F., Navarrete, V., Saña, M., Viñerta, Á., Gassiot, E., 2018. Herders in the mountains and farmers in the plains? A comparative evaluation of the archaeobiological record from Neolithic sites in the eastern Iberian Pyrenees and the southern lower lands. Quat. Int. 484, 75-93.

Aranda Jiménez, G., Lozano Medina, Á., Sánchez Romero, M., Díaz-Zorita Bonilla, M., Bocherens, H., 2018. Chronology of Megalithic Funerary Practices in Southeastern Iberia: The Necropolis of Panoria (Granada, Spain). Radiocarbon, 60 (1), 1-19. DOI: 10.1017/RDC.2017.96.

Balasse, M., Balasescu, A., Tornero, C., Fremondeau, D., Hovsepyan, R., Gillis, R., Popovici, D., 2017. Investigating the scale of herding in Chalcolithic pastoral communities settled along the Danube River in the 5th millenium BC: a case study at Bordusani-Popina and Hârsova-tell (Romania). Quat. Int. 436, 29-40.

Baldellou, V., 1987. Avance al estudio de la Espluga de la Puyascada. Bolskan 4, 3-42.

Bentley, R.A., 2006. Strontium isotopes from the earth to the archaeological skeleton: a review. J. Archaeol. Method Theory 13 (3), 135-187.

Bentley, R.A., 2013. Mobility and the diversity of early Neolithic lives: isotopic evidence from skeletons. J. Anthropol. Archaeol. 32 (3), 303-312.

Bentley, R.A., Knipper, C., 2005. Transhumance at the early Neolithic settlement at Vaihingen (Germany). Antiquity 76 (306).

Bentley, R.A., Price, T.D., Stephan, E., 2004. Determining the 'local' Sr-87/Sr-86 range for archaeological skeletons: a case study from Neolithic Europe. J. Archaeol. Sci. 31 (4), 365-375.

Berdejo, A., Obón, A., Utrilla, P., Laborda, R., Sierra, A., Alcolea, M., Bea, M., Domingo, R., 2018. El abrigo de El Esplugón (Molino de Billobas-Sabiñánigo, Huesca). Un ejemplo para la transición Mesolítico/Neolítico en el prepirineo oscense, in Lorenzo, J.I., Rodanés, J.M. (eds.): II Congreso de Arqueología y Patrimonio Aragonés, Colegio Oficial de Doctores y Licenciados en Filosofía y Letras y en Ciencias de Aragón, Zaragoza, pp. 29-40.

Beyneix, A., 2007. Les comportements funéraires au Néolithique en France méridionale: une vue d'ensemble. L'antropologies 111, 68-78.

Britton, K., Grimes, V., Dau, J., Richards, M.P., 2009. Reconstructing faunal migrations using intra-tooth sampling and strontium and oxygen isotope analyses: a case study of modern caribou (Rangifer tarandus granti). J. Archaeol. Sci. 36 (5), 1163-1172.

Brothwell, D.R., 1993. Desenterrando huesos: la excavación, tratamiento y estudio de restos del esqueleto humano. Fondo de Cultura Económica, Madrid.

Bruzek, J., 2002. A method for visual determination of sex, using the human hip bone Am. J. Phys. Anthropol. 117 (2), 157-168.

Budd, P., Montgomery, J., Barriero, B., Thomas, R.G., 2000. Differential diagenesis of strontium in archaeological human dental tissues. Appl. Geochem. 15, 687-694.

Burton, J.H., Price, T.D., Middleton, W.D., 1999. Correlation of bone Ba/Ca and Sr/Ca due to biological purification of Calcium. J. Archaeol. Sci. 26 (6), 609-616.

Calvo, M.J., 1991b. Excavaciones en el dolmen de la Caseta de las Balanzas en Selva Grande (Almazorre-Bárcabo, Huesca). Arqueología Aragonesa 1986-1987, 87-88.

Calvo, M.J., 1991a. Excavaciones en el dolmen de la Capilleta (Paules de Sarsa-Ainsa, Huesca). Arqueología Aragonesa 1986-1987, 89-90.

Campillo, D., Subirà, M.E., 2004. Antropología física para arqueólogos. Ariel Prehistoria, Barcelona.

Chang, C., 1993. Ethnoarchaeological survey of pastoral transhumance sites in the Grevena region, Greece. J. Field Archaeol. 20, 249-264.

Clemente Conte, I., Gassiot Ballbé, E., Rey Lanaspa, Mazzucco, N., Obea Gómez, L., 2014.
"Cort o Transito" -Coro Trasito- o corral de tránsito: una Cueva pastoral del Neolítico antiguo en el corazón de Sobrarbe. In Clemente, I., Gassiot, E., Rey, J. (eds). Sobrarbe antes de Sobrarbe, pinceladas de historia de los Pirineos, Centro de Estudios de Altoaragoneses, Zaragoza, pp 11-32.

Copeland, S.R., Sponheimer, M., de Ruiter, D.J., Lee-Thorp, J.A., Codron, D., le Roux, P.J., Grimes, V., Richards, M.P., 2011. Strontium isotope evidence forlandscape use by early hominins. Nature 474 (7349), 76-78.

Copeland, S.R., Cawthra, H.C., Fisher, E.C., Lee-Thorp, J.A., Richard, M.C., le Roux, P.J., Hodgkins, J., Marean, C.W., 2016. Strontium isotope investigation of ungulate movement patterns on the pleistocene paleo-agulhas plain of the greater Cape floristic region, South Africa. Quat. Sci. Rev. 141, 65-84.

Díaz-del-Río, P., Waterman, A.J., Thomas, J.T., Peate, D.W., Tykot, R.H., MartínezNavarrete, M.I., Vicent, J.M., 2017. Diet and mobility patterns in the Late Prehistory of central Iberia (4000-1400 cal BC): the evidence of radiogenic $\left({ }^{87} \mathrm{Sr} /{ }^{86} \mathrm{Sr}\right)$ and stable $\left(\delta^{18} \mathrm{O}, \delta^{13} \mathrm{C}\right)$ isotope ratios. Archaeol. Anthropol. Sci. 9, 1439-1452.

Díaz-Zorita Bonilla, M., Beck, J., Bocherens, H., Díaz-del-Río, P., 2018. Isotopic evidence for mobility at large-scale human aggregations in Copper Age Iberia: the mega-site of Marroquíes. Antiquity 92, 991-1007.

Domingo, R., Montes, L., 2016. El asentamiento musteriense al aire libre de Roca San Miguel (Arén, Huesca), in Lorenzo, J.I. y Rodanés, J.M. (eds.): I Congreso de Arqueología y Patrimonio Aragonés. Colegio Oficial de Doctores y Licenciados en Filosofía y Letras y en Ciencias de Aragón, Zaragoza, pp. 17-23.

Domingo, R., Alcolea, M., Bea, M., Mazo, C., Montes, L., Picazo, J., Rodanés, J.M., Utrilla, P., 2018. Call it home: Mesolithic dwellings in the Ebro Basin (NE Spain). Journal of Archaeological Science: Reports, 18, 1036-1052. Doi: 10.1016/j.jasrep.2017.12.034.

Ericson, J.E., 1985. Strontium isotope characterization in the study of prehistoric human ecology, J. Hum. Evol. 14, 503-514.

Fernández-Crespo, T., 2016. El papel del fuego en los enterramientos neolíticos finales/ calcolíticos iniciales de los abrigos de la Sierra de Cantabria y sus estribaciones (valle medio-alto del Ebro). Trabajos de Prehistoria 73 (1), 128-146.

Fernández-Crespo, T., de-la-Rúa, C., 2015. Demographic evidence of selective burial in megalithic graves of northern Spain. J. Archaeol. Sci. 53, 604-617.

Fernández-Crespo, T., Schulting, R.J., 2017. Living different lives: early social differentiation identified through linking mortuary and isotopic variability in Late Neolithic/ Early Chalcolithic north-central Spain. PLoS ONE 12 (9), e0177881.

Fernández-Crespo, T., Mujika, J.A., Ordoño, J., 2017. Aproximación al patrón alimentario de los inhumados en la cista de la Edad del Bronce de Ondarre (Aralar, Guipúzcoa) a través del análisis de isótopos estables de carbono y nitrógeno sobre colágeno óseo. Trabajos de Prehistoria 73 (2), 325-334.

Fernández-Eraso, J., Mujika-Alustiza, J.A., 2013. La estación megalítica de la Rioja Alavesa: Cronología, orígenes y ciclos de utilización/The megalithic station of the Rioja Alavesa: chronology, origins and utilisation cycles. Zephyrus 71, 89-106.

Fontanals-Coll, M., Díaz-Zorita Bonilla, M., Subirà, M.E., 2015. A Palaeodietary Study of Stable Isotope Analysis from a High-status Burial in the Copper Age: The Montelirio Megalithic Structure at Valencina de la Concepción-Castilleja de Guzmán, Spain. Int. J. Osteoarchaeol. 26 (3), 447-459.

García-Borja, P., Perez Fernandez, A., Biosca Cirujeda, V., Ribera i Gomes, A., SalazarGarcía, D.C., 2013. Los restos humanos de la Coveta del Frare (Font de la Figuera, Valencia), in García-Borja, P., Revert, E., Ribera, A., Biosca, V., (eds.), El Naiximent d' un Poble. Historia i Arqueologia de la Font de la Figuera, Ajuntament de la Font de la Figuera, pp. 47-60.

Gassiot Balbé, E., Julià Brugués, R., Rodríguez Antón, D., Bal-Serin, M.-C., Pèlachs Mañosa, A., Mazzucco, N., Pérez Obiol, R., 2014. La alta montaña durante la Prehistoria: 10 años de investigación en el Pirineo catalán occidental. Trabajos de Prehistoria 71 (2), 261-281.

Geddes, D.S., 1983. Neolithic transhumance in the mediterranean pyrenees. World Archaeol. 15, 51-66.

Gerling, C., Bánffy, E., Dani, J., Köhler, K., Kulcsár, G., Pike, A.W.G., Szeverényi, V., Heyd, V., 2012. Immigration and transhumance in the Early Bronze Age Carpathian basin: the occupants of a kurgan. Antiquity 86, 1097-1111.

Gimeno, B., 2009. Estudio antropológico de la cueva sepulcral de Loarre. Salduie 9, 369-392.

González-Sampériz, P., Aranbarri, J., Pérez-Sanz, A., Gil-Romera, G., Moreno, A., Leunda, M., Sevilla-Callejo, M., Corella, J.P., Morellón, M., Oliva, B., Valero-Garcés, B., 2017. Environmental and climate change in the southern Central Pyrenees since the Last Glacial Maximum: a view from the lake records. CATENA 149, 668-688.

Goude, G., Castorina, F., Herrscher, E., Cabut, S., Tafuri, M.A., 2012. First strontium isotope evidence of mobility in the neolithic of southern France. Eur. J. Archaeol. 15 (3), 421-439.

Guixé, E.G., 2009. Estudi paleoantropològic i paleopatològic del sepulcre col lectiu de Forat de Conqueta (Santa Linya, Lleida). Treballs d'Arqueologia 17, 37-98.

Haak, W., Brandt, G., de Jong, H.N., Meyer, C., Ganslmeier, R., Heyd, V., Hawkesworth, C., Pike, A. W.G., Meller, H., Alt, K.W., 2008. Ancient DNA, Strontium isotopes, and osteological analyses shed light on social and kinship organization of the Later Stone Age. Proceedings of the National Academy of Sciences, pnas-0807592105.

Haak, W., Lazaridis, I., Patterson, N., Rohland, N., Mallick, S., Llamas, B., Brandt, G., Nordenfelt, S., Harney, E., Stewardson, K., Fu, Q., Mittnik, A., Bánffy, E., Economou, C., Francken, M., Friederich, S., Garrido Pena, R., Hallgren, F., Khartanovich, V., Khokhlov, A., Kunst, M., Kuznetsov, P., Meller, H., Mochalov, O., Moiseyev, V., Nicklisch, N., Pichler, S.L., Risch, R., Rojo Guerra, M.A., Roth, C., Szécsényi-Nagy, A., Wahl, J., Meyer, M., Krause, J., Brown, D., Anthony, D., Cooper, A., Alt, K.W., Reich, D., 2015. Massive migration from the steppe was a source for Indo-European languages in Europe. Nature 522, 207.

Hillson, S., 1996. Dental Anthropology. Cambridge University Press, Cambridge.

Hoppe, K.A., Koch, P.L., Carlson, R.W., Webb, S.D., 1999. Tracking mammoths and mastodons: reconstruction of migratory behavior using strontium isotope ratios. 
Geology 27 (5), 439-442.

Kienlin, T.L., Valde-Nowak, P., 2002-2004. Neolithic transhumance in the Black Forest Mountains, sw, Germany. J. Field Archaeol. 29, 29-44.

Knipper, C., Mittnik, A., Massy, K., Kociumaka, C., Kucukkalipci, I., Maus, M., Wiitenborn, F., Metz, S.E., Staskiewicz, A., Krause, J., Stockhammer, P.W., 2017. Female exogamy and gene pool diversification at the transition from the Final Neolithic to the Early Bronze Age in central Europe. Proceedings of the National Academy of Sciences, 201706355.

Laborda, R., Villalba-Mouco, V., Lanau, P., Gisbert, M., Sebastián, M., Domingo, R., Montes, L., 2017. El Puerto Bajo de Góriz (Parque Nacional de Ordesa y Monte Perdido). Ocupación y explotación de un paisaje de alta montaña desde la prehistoria hasta el siglo XX. Bolskan 26, 9-30.

Lancelotti, C., Balbo, A., Madella, M., Iriarte, E., Rojo, M., Royo, J.I., Tejedor, C., Garrido, R., García, I., Arcusa, H., Pérez, G., Peña-Chocarro, L., 2014. The missing crop: investigating the use of grasses at Els Trocs, a Neolithic cave site in the Pyrenees (1564 m asl). J. Archaeol. Sci. 42, 456-466.

López-Costas, O., Müldner, G., Martínez Cortizas, A., 2015. Diet and lifestyle in Bronze Age Northwest Spain: the collective burial of Cova do Santo. J. Archaeol. Sci. 55, 209-218.

Lorenzo, J.I., 2014. Estudio antropológico de los restos de Forcas II. In: Utrilla, P., Mazo, C. (Eds.), La Peña de las Forcas (Graus, Huesca). Universidad de Zaragoza, Zaragoza, Un asentamiento estratégico en la confluencia del Ésera y el Isábena, pp. 337-341.

Lugli, F., Cipriani, A., Arnaud, J., Arzarello, M., Peretto, C., Benazzi, S., 2017. Suspected limited mobility of a Middle Pleistocene woman from Southern Italy: strontium isotopes of human deciduous tooth. Sci. Rep. 7, 8615.

Martínez-Moreno, J., Mora, R., de la Torre, I., 2010. The Middle-to-upper Palaeolithic transition in Cova Gran (Catalunya, Spain) and the extinction of Neanderthals in the Iberian peninsula. J. Hum. Evol. 58 (3), 211-226.

Mazzucco, N., Clemente-Conte, I., Baldellou, V., Gassiot Ballbè, E., 2013. The management of lithic resources during the V millennium cal BC at Espluga de la Puyascada (La Fueva, Huesca). Preistoria Alpina 47/I, 17-30.

McClure, S.B., García, O., Roca de Togores, C., Culleton, B.J., Kennett, D.J., 2011. Osteological and paleodietary investigation of burials from Cova de la Pastora, Alicante, Spain. J. Archaeol. Sci. 38 (2), 420-428.

Montes, L., Domingo, R., 2001-2002. Epipaleolítico y Neolítico en las sierras exteriores de Aragón. Prospecciones, Sondeos y excavaciones 2001. Salduie 2, 323-336.

Montes, L., Martínez-Bea, 2006. El yacimiento campaniforme de Cueva Drólica (Sarsa de Surta, Huesca). Salduie 6, 297-316.

Montes, L., Bea, M., Domingo, R., Sánchez, P., Alcolea, M., Sebastián, M., 2016b. La gestión prehistórica de un territorio en la montaña Prepirenaica: Tierra Bucho (Huesca, España). Munibe Antropologia-Arkeologia 67, 349-362.

Montes, L., Domingo, R., 2014. La ocupación de las Sierras Exteriores durante el Calcolítico. In: Utrilla, P., Mazo, C. (Eds.), La Peña de las Forcas (Graus, Huesca) Universidad de Zaragoza, Zaragozapp, Un asentamiento estratégico en la confluencia del Ésera y el Isábena, pp. 409-426.

Montes, L., Domingo, R., Sebastián, M., Lanau, P., 2016a. ¿Construyendo un paisaje? Megalitos, arte esquemático y cabañeras en el Pirineo central. ARPI 04, 248-263.

Mora, R., Martínez-Moreno, J., Casanova, J., 2008. Abordando la noción de "variabilidad musteriense" en Roca dels Bous (Prepirineo suroriental, Lleida). Trabajos de Prehistoria 65 (2), 13-28.

Olalde, I., Brace, S., Allentoft, M.E., Armit, I., Kristiansen, K., Booth, T., Rohland, N., Mallick, S., Szécsényi-Nagy, A., Mittnik, A., Altena, E., Lipson, M., Lazaridis, I., Harper, T.K., Patterson, N.J., Broomandkhoshbacht, N., Diekmann, Y., Faltyskova, Z. Fernandes, D.M., Ferry, M., Harney, E., de Knijff, P., Michel, M., Oppenheimer, J., Stewardson, K., Barclay, A., Alt, K.W., Liseau, C., Ríos, P., Blasco, C., Vega Miguel, J. Menduiña García, R., Avilés Fernández, A., Bánffy, E., Bernabò-Brea, M., Billoin, D. Bonsall, C., Bonsall, L., Allen, T., Büster, L., Carver, S., Castells Navarro, L., Craig, O.E., Cook, G.T., Cunliffe, B., Denaire, A., Dinwiddy, K.E., Dodwell, N., Ernée, M., Evans, C., Kuchařík, M., Farré, J.F., Fowler, C., Gazenbeek, M., Garrido Pena, R., Haber-Uriarte, M., Haduch, E., Hey, G., Jowett, N., Knowles, T., Massy, K., Pfrengle, S., Lefranc, P., Lemercier, O., Lefebvre, A., Heras, C., Galera, V., Bastida, A., Lomba, J., Majó, T., McKinley, J.I., McSweeney, K., Gusztáv, M.B., Modi, A., Kulcsár, G., Kiss, V., Czene, A., Patay, R., Endródi, A., Köhler, K., Hajdu, T., Szeniczey, T., Dani, J., Bernert, Z., Hoole, M., Cheronet, O., Velemnský, P., Dobeš, M., Candilio, F., Brown, F., Flores, R., Herrero-Corral, A.M., Tusa, S., Carnieri, E., Lentini, L., Valenti, A., Zazini, A., Waddington, C., Delibes, G., Guerra-Doce, E., Neil, B., Brittain, M., Luke, M., Mortimer, R., Desideri, J., Besse, M., Brüken, G., Furmanek, M., Haluszko, A., Mackiewicz, M., Rapiński, A., Leach, S., Soriano, I., Lillios, K.T., Cardoso, J.L., Pearson, M.P., Włodarczak, P., Price, T.D., Prieto, P., Rey, P.J., Risch, R., Rojo Guerra, M.A., Schmitt, A., Serralongue, J., Silva, A.M., Smrčka, V., Vergnaud, L., Zilhão, J., Caramelli, D., Higham, T., Thomas, M.G., Kennett, D.J., Fokkens, H., Heyd, V., Sheridan, J.A., Sjögren, K.G., Stockhammer, P.W., Krause, J., Pinhasi, R., Haak, W., Barnes, I., Lalueza-Fox, C., Reich, D., 2018. The Beaker phenomenon and the genomic transformation of Northwest Europe. Nature 555, 190-196.

Olalde, I., Mallick, S., Patterson, N., Rohland, N., Villalba-Mouco, V., Silva, M., Dulias, K. Edwards, C.J., Gandini, F., Pala, M., Soares, P., Ferrando-Bernal, M., Adamski, N., Broomandkhoshbacht, N., Cheronet, O., Culleton, B.J., Fernandes, D., Lawson, A.M., Mah, M., Oppenheimer, J., Stewardson, K., Zhang, Z., Jiménez Arenas, J.M., Toro Moyano, I.J., Salazar-García, D.C., Castanyer, P., Santos, M., Tremoleda, J., Lozano, M., García Borja, P., Fernández-Eraso, J., Mujika-Alustiza, J.A., Barroso, C., Bermúdez, F.J., Viguera Mínguez, E., Burch, J., Coromina, N., Vivó, D., Cebrià, A., Fullola, J.M., García-Puchol, O., Morales, J.I., Oms, F.X., Majó, T., Vergès, J.M., DíazCarvajal, A., Ollich-Castanyer, I., López-Cachero, F.J., Silva, A.M., Alonso-Fernández, C., Delibes de Castro, G., Jiménez Echevarría, J., Moreno-Márquez, A., Pascual Berlanga, G., Ramos-García, P., Ramos-Muñoz, J., Vijande Vila, E., Aguilella Arzo, G., Esparza Arroyo, A., Lillios, K.T., Mack, J., Velasco-Vázquez, J., Waterman, A., Benítez de Lugo Enrich, L., Benito Sánchez, M., Agustí, B., Codina, F., de Prado, G., Estalrrich, A., Fernández Flores, A., Finlayson, C., Finlayson, G., Finlayson, S., Giles-Guzmán, F., Rosas, A., Barciela González, V., García Atiénzar, G., Hernández Pérez, M.S., Llanos, A., Carrión Marco, Y., Collado Beneyto, I., López-Serrano, D., Sanz Tormo, M., C. Valera, A.C., Blasco, C., Liesau, C., Ríos, P., Daura, J., de Pedro Michó, M.J., DiezCastillo, A.A., Flores Fernández, R., Francès Farré, J., Garrido-Pena, R., Gonçalves, V. S., Guerra-Doce, E., Herrero-Corral, A.M., Juan-Cabanilles, J., López-Reyes, D., McClure, S.B., Merino Pérez, M., Oliver Foix, A., Sanz Borràs, M., Sousa, A.C., Vidal Encinas, J.M., Kennett, D.J., Richards, M.B., Alt, K.W., Haak, W., Pinhasi, R., LaluezaFox, C., Reich, D., 2019. The genomic History of the Iberian Peninsula over the past 8000 years. Science 363 (6432), 1230-1234.

Olivier, G., 1960. Practique anthropologique. Vigot, Paris.

Ortner, D.J., 2003. Identification of Pathological Conditions in Human Skeletal Remains. Academic Press, San Diego.

Pastor, Ma.V., Vicente, D., 2009. La cueva sepulcral neolítica/calcolítica de San Juan en Loarre (Huesca). Salduie 9, 335-367.

Pérez-Romero, A., Iriarte, E., Galindo-Pellicena, M.A., García-González, R., Rodríguez, L., Castilla, M., Francés-Negro, M., Santos, E., Valdiosera, C., Arsuaga, J.L., Alday, A., Carretero, J.M., 2017. An unusual Pre-Bell Beaker copper age cave burial context from El Portalón de Cueva Mayor site (Sierra de Atapuerca, Burgos). Quat. Int. 433, $142-155$.

Pin, C., Briot, D., Bassin, C., Poitrasson, F., 1994. Concomitant separation of strontium and samarium-neodymium for isotopic analysis in silicate samples, based on specific extraction chromatography. Anal. Chim. Acta 298 (2), 209-217.

Price, T.D., Bentley, R.A., Gronenborn, D., Lüning, J., Wahl, J., 2001. Human migration in the linearbandkeramik of central europe. Antiquity 75, 593-603.

Price, T.D., Burton, J.H., Bentley, R.A., 2002. The characterization of biologically available strontium isotope ratios for the study of prehistoric migration. Archaeometry 44 (1), 117-135.

Reimer, P.J., Bard, E., Bayliss, A., Beck, J.W., Blackwell, P.G., Bronk Ramsey, C., Grootes, P.M., Guilderson, T.P., Haflidason, H., Hajdas, I., Hatte, C., Heaton, T.J., Hoffmann, D.L., Hogg, A.G., Hughen, K.A., Kaiser, K.F., Kromer, B., Manning, S.W., Niu, M., Reimer, R.W., Richards, D.A., Scott, E.M., Southon, J.R., Staff, R.A., Turney, C.S.M., Van der Plicht, J., 2013. IntCal13 and Marine13 radiocarbon age calibration curves 050,000 Years cal BP. Radiocarbon 55 (4), 1869e1887.

Rojo, M., Arcusa, H., Peña, L., Royo, J.I., Tejedor, C., García, I., Garrido, R., Moreno, M., Pimenta, C., Mazzucco, N., Gibaja, J.F., Pérez, G., Jiménez, I., Iriarte, E., Alt, K.W., 2014. Los primeros pastores trashumantes de la Alta Ribagorza. In: Clemente, I., Gassiot, E., Rey, J. (Eds.), Sobrarbe antes de Sobrarbe, pinceladas de historia de los Pirineos. Centro de Estudios de Sobrarbe (CES) \& Instituto de Estudios Altoaragoneses, Zaragoza, pp. 127-151.

Rojo, M., Royo, J.I., Garrido, R., García-Martínez, I., Tejedor, C., Arcusa H., PeñaChocarro, L., Moreno-García, M., 2015. La Cueva de Els Trocs: un asentamiento del Neolítico Antiguo junto al Pirineo axial, in: Gonçalves, V., Diniz, M., Sousa, A.C. (Eds. ), Actas del $5^{\circ}$ Congreso do Neolítico Peninsular, UNIARQ, Estudos \& Memórias, 8 , Lisboa, pp.189-197.

Rojo, M., Peña-Chocarro, L., Royo, J.I., Tejedor, C., García-Martínez, I., Arcusa, H., Garrido, R., Moreno, M., Mazzucco, N., Gibaja, J.F., Ortega, D., Kromer, B., Alt, K.W., 2013. Pastores trashumantes del Neolítico antiguo en un entorno de alta montaña: secuencia crono-cultural de la Cova de Els Trocs (San Feliú de Veri, Huesca). BSAA Arqueología 79, 9-55.

Salazar García, D.C., 2011. Aproximación a la dieta de la población calcolítica de La Vital a través del análisis de isótopos estables del carbono y del nitrógeno sobre restos óseos, in: Pérez, G., Bernabeu, J., Carrión, Y., García-Puchol, O., Molina, LL., Gómez, M., (eds.), Vida y muerte en la desembocadura del Serpis durante el III y el I milenio a.C., Museu de Prehistòria de València-Diputación de Valencia, València, pp. 139-149.

Salazar-García, D.C., García-Puchol, O., de Miguel-Ibañez, M.P., Talamo, S., 2016. Earliest evidence of neolithic collective burials from Eastern Iberia: radiocarbon dating at the archaeological site of Les Llometes (Alicante, Spain). Radiocarbon 58 (3), 679-692.

Salazar-García, D.C., 2014. Estudi de la dieta en la poblacio de Cova dels Diablets mitjancant analisi d'isotops estables del carboni i del nitrogen en collagen ossi. Resultats preliminars, in: Aguilella Arzo, G.A., Monroig, D., García-Borja, P. (Eds.), La Cova dels Diablets (Alcalà de Xivert, Castelló). Prehistòria a la Serra d'Irta, Diputació de la Castelló, Castellón, pp. 67-78.

Sarasketa-Gartzia, I., Villalba-Mouco, V., le Roux, P., Arrizabalaga, Á., Salazar-García, D.C., 2018b. Late Neolithic-Chalcolithic socio-economical dynamics in Northern Iberia. A multi-isotope study on diet and provenance from Santimamiñe and Pico Ramos archaeological sites (Basque Country, Spain). Quat. Int. 481, 14-27.

Sarasketa-Gartzia, I., Villalba-Mouco, V., Le Roux, P., Arrizabalaga, Á., Salazar-García, D.C., 2018a. Anthropic resource exploitation and use of the territory at the onset of social complexity in the Neolithic-Chalcolithic Western Pyrenees: a multi-isotope approach. Archaeol. Anthropol. Sci. https://doi.org/10.1007/s12520-018-0678-7.

Schuhmacher, T.X., Banerjee, A., 2012. Procedencia e intercambio de marfil en el Calcolítico de la Península Ibérica. Rubricatum 5, 289-298.

Sjögren, K.G., Price, T.D., Kristiansen, K., 2016. Diet and mobility in the Corded Ware of Central Europe. PLoS ONE 11 (5), e0155083.

Sola, C., Montes, L., Domingo, R., 2016. Rotas en mil pedazos: un estudio preliminar de esquirlas óseas del sitio musteriense de Roca San miguel (Arén, Huesca). Salduie 16, 55-62.

Szécsényi-Nagy, A., Roth, C., Brandt, G., Rihuete-Herrada, C., Tejedor-Rodríguez, C., Held, P., García-Martínez-de-Lagrán, I., Arcusa Magallón, H., Zesch, S., Knipper, C., Bánffy, E., Friederich, S., Meller, H., Bueno, P., Barroso, R., Balbín, R., HerreroCorral, A.M., Flores, R., Alonso, C., Jiménez, J., Rindlisbacher, L., Oliart, C., Fregeiro, M.I., Soriano, I., Vicente, O., Micó, R., Lull, V., Soler, J., López, J.A., Roca de Togores, 
C., Hernández, M.S., Jover, F.J., Lomba, J., Avilés, A., Lillios, K.T., Silva, A.M., Magalhães, M., Oosterbeek, L.M., Cunha, C.,Waterman, A.J., Roig, J., Martínez, A. Ponce, J., Hunt, M., Mejías-García, J.C., Carlos Pecero, J.C., Cruz-Auñón, R., Tomé, T., Carmona, E., Cardoso, J.L., Araújo, A.C., Liesau von Lettow-Vorbeck, C., Blasco, C., Ríos, P., Pujante, A., Royo-Guillén, J.I., Esquembre, M.A., Dos Santos, V.M., Parreira, R., Morán, E., Méndez, E., Vega y Miguel, J., Menduiña, R., Martínez, V., López, O., Krause, J., Pichlerf, S.L., Garrido-Pena, R., Kunst, M., Risch, R., RojoGuerra, M.A., Haak, W., Alt, K.W., 2017. The maternal genetic make-up of the Iberian Peninsula between the Neolithic and the Early Bronze Age. Scientific Reports 7 (1), 15644.

Tornero, C., Aguilera, M., Ferrio, J.P., Arcusa, H., Moreno-García, M., Garcia-Reig, S., Rojo-Guerra, M., 2018. Vertical sheep mobility along the altitudinal gradient through stable isotope analyses in tooth molar bioapatite, meteoric water and pastures: a reference from the Ebro valley to the Central Pyrenees. Quat. Int. 484, 94-106.

Ubelaker, D., 1978. Human skeletal remains. Excavation, analysis, interpretation. Chicago.

Utrilla, P., Laborda, R., 2018. La Cueva de Chaves (Bastaras, Huesca): 15000 años de ocupación prehistórica. Trabajos de Prehistoria 75 (2), 248-269.

Utrilla, P., Mazo, C., 2014. La Peña de las Forcas (Graus, Huesca). Universidad de Zaragoza, Zaragoza.

Utrilla, P., Montes, L., Mazo, C., Martínez Bea, M., Domingo, R., 2009. El Mesolítico geométrico en Aragón. In: Utrilla, P., Montes, L. (Eds.), El Mesolítico Geométrico en la Península Ibérica. El desarrollo de las industrias líticas geométricas del VIII al VII milenio BP, Universidad de Zaragoza, Zaragoza, II Reunión sobre Mesolítico. El Mesolítico Geométrico, pp. 131-190.

Utrilla, P., Montes, L., Fernanda, B., Torres Pérez-Hidalgo, T.J., Ortiz Menéndez, J.E., 2010. La cueva de Gabasa revisada 15 años después: un cubil para las hienas y un cazadero para los Neandertales. Zona Arqueológica 13, 376-389.

Utrilla, P., Mazo, C., Domingo, R., 2015. Fifty thousand years of prehistory at the cave of Abauntz (Arraitz, Navarre): a nexus point between the Ebro Valley, Aquitaine and the Cantabrian corridor. Quat. Int. 364, 294-305.

Villalba-Mouco, V., Martínez-Labarga, C., Utrilla, P., Laborda, R., Ignacio, J., SalazarGarcía, D.C., 2018b. Reconstruction of human subsistence and husbandry strategies from the Iberian Early Neolithic: a stable isotope approach. Am. J. Phys. Anthropol. 167 (2), 257-271.

Villalba-Mouco, V., Sarasketa-Gartzia, I., Utrilla, P., Oms, F.X., Mazo, C., Mendiela, S. Cebriá, A., Salazar-García, D.C., 2018a. Stable isotope ratio analysis of bone collagen as indicator of different dietary habits and environmental conditions in northeastern Iberia during the 4th and 3rd millennium cal B.C. Archaeol. Anthrop. Sci. https://doi. org/10.1007/s12520-018-0657-z.

Villalba-Mouco, V., Sauqué, V., Sarasketa-Gartzia, I., Pastor, M.V., le Roux, P.J., Vicente, D., Utrilla, P., Salazar-García, D.C., 2018c. Territorial mobility and subsistence strategies during the Ebro Basin Late Neolithic-Chalcolithic: a multi-isotope approach from San Juan cave (Loarre, Spain). Quat. Int. 481, 28-41.

Waterman, A.J., Peate, D.W., Silva, A.M., Thomas, J.T., 2014. In search of homelands: using strontium isotopes to identify biological markers of mobility in late prehistoric Portugal. J. Archaeol. Sci. 42, 119-127.

Waterman, A.J., Tykot, R.H., Silva, A.M., 2015. Stable Isotope Analysis of Diet-based Social Differentiation at Late Prehistoric Collective Burials in South-Western Portugal. Archaeometry 58 (1), 131-151.

Willmes, M., Bataille, C.P., James, H.F., Moffat, I., McMorrow, L., Kinsley, L., Armstrong, R.A., Eggins, S., Grün, R., 2018. Mapping of bioavailable strontium isotope ratios in France for archaeological provenance studies. Appl. Geochem. 90, 75-86. 